\title{
Meslek Yüksekokullarında Öğrenci Başarısı Üzerine Bir Çalışma: Eğirdir Meslek Yüksekokulu Muhasebe Programı Örneği
}

Nurdan KUŞAT*

\section{$\ddot{O Z Z E T}$}

Verilen eğitimin ve edinilen bilginin en kısa sürede ülke ekonomisine kazandırılmasında en yüksek paya sahip olan okulların meslek yüksekokulları olduğu kesindir. Özellikle Avrupa Birliği'ne uyum süreciyle 21.yy'ın ilk çeyreğinden itibaren daha çok dikkat çekmeye başlayan bu ĕgitim kurumları kısa sürede pek çok yeni uygulamaya tabi tutulmuştur. Meslek liselerinden sınavsız geçişle (METEB) öğrenci alınması yoluyla başlayan yenilikleri, Bologna süreci ve IKMEB adıyla anılan yeni uygulamalar izlemiştir.

Bu çalışma ile Süleyman Demirel Üniversitesi Ĕgirdir Meslek Yüksekokulu Muhasebe ve Vergi Uygulamalar Programına 2012-2013 eğitim-öğretim yılında kayıt yaptıran ögrencilerin cinsiyetleri, ögretim türleri, mezun olduklarl liseler ve belirlenen 2 dersteki başarıları karşılaş̧ırılmak istenmiştir. Yapılan varyans analizi sonucunda ders* cinsiyet*öğretim türü̈mezuniyet dörtlü interaksiyonu ve tüm 3'lü ve 2'li interaksiyonlar istatistik olarak önemli bulunmamıştır.

Anahtar Kelimeler: Bilgi Çă̆l, Meslek Yüksekokulu, Sınavsız Geçiş, Mesleki Eğitim, Muhasebe Programi..

JEL Sinıflandırması: M41, I21.

A Study On The Vocational School About Student Success: The Case Of Ë̆irdir Vocational School Accounting Program

\section{ABSTRACT}

As soon as the education and the knowledge are acquired in schools that the highest share in bringing the country's economy is certainly vocational schools. In particular the process of the European Union of the 21 st century that it started to attract more attention from the first quarter of the educational institutions are subject to the application as soon as possible so many new. The transition from vocational high schools without examination (METEB) taking students beginning by taking innovations, known as the Bologna process and the IKMEB are following by new applications.

In this study is planning to compare in the 2012-2013 academic year Süleyman Demirel University, Eğirdir Vocational School Accounting and Tax Applications Program's enrolling students gender, academic types, they have graduated from high school and the achievements of the two lessons. As a result of the analysis of variance type of course * gender * education * 3 and 2-graduation quadruple interaction, and all interactions were not statistically significant.

Keywords: Information Age, Vocational School, Without Examanition Transfer, Vocational Education, Accounting Program.

Jel Classification: M41, I21.

\footnotetext{
* Dr. Nurdan Kuşat, Süleyman Demirel Üniversitesi, Eğirdir Meslek Yüksekokulu, nurdankusat@sdu.edu.tr
} 


\section{GíRiş̧}

Yeni ekonomik düzen sürdürülebilir kalkınma için gerekli olan yapı taşlarının neler olduğunu tüm ayrıntılarıyla ortaya çıkarmıştır. Bir ülke için kalkınmayı sağlamak ne kadar zorsa, bu kalkınmayı sürdürülebilir kılmak ondan çok daha zordur.

Sürdürülebilir kalkınmanın sağlanmasında en önemli faktörlerden birisinin beşeri sermaye olduğu bir gerçektir. Bu faktörden en yüksek düzeyde fayda sağlamak için, bu faktöre üstün bir donanım kazandırılmasına ihtiyaç vardır. Ülkedeki mevcut işgücünün iş hayatına uygun bir yapıya kavuşturulmasında da mesleki eğitimin yeri oldukça önemlidir.

Mesleki eğitim kavramı; gerek tanımı gerekse amacı açısından akla ilk olarak meslek yüksekokullarını getirir. Meslek yüksekokulları Türkiye'de yükseköğrenimin içerisinde ön lisans programları olarak adlandırılan, asgari 2 yıllık eğitim ve öğretim sürecini kapsayan, temel amacı sanayi, ticaret ve hizmet ana sektörlerine nitelikli ara elemanı yetiştirmek olan yükseköğretim kurumlarıdır. Bu nedenle de mesleki eğitim ve meslek yüksekokulları günümüzde tüm sektörler için yaşamsal bir öneme sahiptir. 4702 sayılı kanun ile 2002-2003 eğitim öğretim döneminde meslek liselerinden meslek yüksekokullarına sınavsız geçiş yolunun açılması sayesinde popülaritesi artan bu kurumların maalesef eğitim kalitesinin azaldığı dikkat çekmektedir.

$\mathrm{Bu}$ çalışmada meslek yüksekokullarının genel durumu, bu kurumların yasal görünümü çerçevesinde özetlenerek, Süleyman Demirel Üniversitesi Eğirdir Meslek Yüksekokulu Muhasebe ve Vergi Uygulamaları Programına 2012-2013 yllında kayıt yaptıran öğrencilerin, başarı durumları bazı demografik özellikler çerçevesinde SPSS istatistik programında varyans analizi ile değerlendirilecektir.

\section{TÜRKIYE'DE MESLEK YÜKSEKOKULLARININ KAVRAMSAL ÇERÇEVESI}

Türkiye'de meslek yüksekokullarının yasal çerçevesi 2547 sayılı "Yükseköğretim Kanunu" ile belirlenmiştir. Bu kanunda geçen ve meslek yüksekokullarını ilgilendiren tanımlar ise şu şekildedir (yok.gov.tr,2013):

2547 sayll kanun 3. Madde ı bendi: "Meslek Yüksekokulu: Belirli mesleklere yönelik ara insan gücü yetiştirmeyi amaçlayan dört yarıylllı eğitim-öğretim sürdüren bir yükseköğretim kurumudur".

2547 sayll kanun 3. Madde $r$ bendi: "Ön Lisans: Ortaöğretime dayal1, en az dört yarıyıllık bir programı kapsayan, ara insan gücü yetiştirmeyi amaçlayan veya lisans öğretiminin ilk kademesini teşkil eden bir yükseköğretimdir”.

Kuzgun (2013) üniversitelerin üç amacı olduğundan bahseder: (1) Bilimsel araştırma yapmak ve bilgi üretmek, (2) meslek elemanı yetiştirmek ve (3) kültür kazandırmak.

Meslek yüksekokullarında ise temel amaç 2547 sayılı kanunun da vurgu yaptığı bu 3 amaçtan 2.sinde yoğunlaşmaktadır. Türkiye'de meslek yüksekokulu sayılarının fazlalığı, ama 
buna karşın akademik kadronun sayıca yetersizliği; özellikle birinci amacın meslek yüksekokulları için geri plana itilmesine sebep olmuştur (Kuşat ve Dolmacı 2011:3). Gerçekte de meslek yüksekokulları kuruluş amaçları gereği bilimsel araştırma kurumu olmaktan ziyade, meslek elemanı yetiştiren kurumlar olarak kabul edilmektedirler.

Türkiye'de Devlet Üniversitesi, Vakıf Üniversitesi ve Diğer Yükseköğretim Kurumları başlıkları altında faaliyet gösteren üniversite ve meslek yüksekokullarının sayısı Tablo 1'de verilmektedir.

Tablo 1: Türkiye' de Üniversite ve Meslek Yüksekokulu Sayıları

\begin{tabular}{|r|c|c|}
\hline Yüksek Öğretim Kurumu Türü & Sayı & Meslek Yüksekokulu SayıSı \\
\hline Devlet Üniversitesi & 103 & 606 \\
\hline Vakıf Üniversitesi & 65 & 65 \\
\hline Diğer Yükseköğrenim Kurumları & 13 & - \\
\hline TOPLAM & $\mathbf{1 8 1}$ & $\mathbf{6 1 3}$ \\
\hline
\end{tabular}

Kaynak: yok.gov.tr, 2013.

Tablo 1'den anlaşılacağı üzere, devlet üniversitesi başına yaklaşık 6 tane meslek yüksekokulu düşmektedir. Vakıf üniversitelerinde ise bu sayı üniversite başına bir meslek yüksekokulu şeklindedir. Türkiye'deki devlet üniversiteleri içerisinde meslek yüksekokullarına ağırlık verilmesinin en önemli sebebi olarak ülkede uygulanan kalkınma ve eğitim politikaları gösterilebilir. Yüksek Öğretim Kurumunun (YÖK) Milli Eğitim Bakanlığı, diğer ilgili bakanlıklar, yerel yönetimler, iş çevreleri ve Sivil Toplum Kuruluşları ile gerçekleştirdiği ortak çalışmalar da bu gelişmeleri desteklemektedir.

Tablo 1'de Vakıf Meslek Yüksekokullarından bahsedilmemektedir. Bu meslek yüksekokulları üniversite kurma şartına bağlı olmaksızın 4702 Sayılı Yasa hükümlerine göre vakıflar tarafından kurulan meslek yüksekokullarıdır ve şu anda bu çerçevede kurulmuş 7 adet vakıf meslek yüksekokulu bulunmaktadır (yok.gov.tr, 2013).

Türkiye'de 2011-2012 eğitim öğretim döneminde ön lisans ve lisans düzeyinde yükseköğretim kurumlarına kayıt yaptıran öğrenci sayıları Tablo 2'de yer almaktadır.

Tablo 2: 2011-2012 Eğitim Öğretim Dönemi Yüksek Öğretime Yerleştirilme Sayıları

\begin{tabular}{|r|c|c|c|}
\hline Yerleştirilen Program & Sayı & Öğretim Elemanı SayıSı & Öğretim Elemanı Başına Düşen Öğrenci SayıSı \\
\hline Ön Lisans & 280.874 & 11.675 & 24 \\
\hline Lisans & 337.291 & 97.675 & 3.5 \\
\hline Toplam & 618.165 & 109.350 & 27.5 \\
\hline
\end{tabular}

Kaynak: osym.gov.tr, 2013

Yukarıdaki tablo sonuçlarında ön lisans programlarında eğitim veren öğretim elemanları başına düşen öğrenci sayısının çokluğu dikkat çekmektedir. 2000 yılı başlarından itibaren Avrupa Birliği'ne uyum sürecinde sürekli olarak yenilenen, müfredatı ve giriş koşulları sürekli değişsirilen meslek yüksekokullarının, maalesef eğitim kadrosu açısından unutulduğu bu tabloya bakılarak söylenebilir. 2007 yılında gerçekleştirilen Uluslararası Mesleki Ve Teknik Eğitim Konferansı'nın Yükseköğretimde Uygulama Ağırlıklı Yeni 
Açılımlar isimli çalışma grubu raporunda ayrıca meslek yüksekokulu sayılarının, ülke genelinde dağılımı ve il merkezleri, ilçe ve hatta beldelerde eğitim öğretim veriyor olmalarının kalite problemini beraberinde getirdiği sonucuna varılmıştır (YÖK, 2007:95).

Yeni ekonomik düzen, uluslararası rekabet koşullarına uyum sağlayabilecek mal ve hizmetlerin üretilmesinde görev alacak iş gücünün yetiştirilmesine duyulan gereksinimi çok daha gerçekçi bir şekilde gözler önüne sermiştir. Bu yeni ekonomik düzenin ortaya koyduğu bir diğer gerçek ise bugüne kadar uygulanmakta olan yaklaşımlardan çok daha farklı yaklaşımlara ihtiyaç olduğu konusundadır. Bu bağlamda "Mesleki ve Teknik Orta ve Yükseköğretim Kurumları Arasında Program Bütünlüğünün ve Devamlılığının Sağlanması Projesi" veya diğer adıyla "Sınavsız Geçiş Projesi" nin meslek yüksekokullarında okuyan öğrenci sayılarının artırılmasına ve dolaysıyla mesleki ve teknik eğitimde okullaşma oranının yükseltilerek çağdaş ülkeler seviyesine yaklaştırılmasına önemli katkılarda bulunacağı düşünülmüsştür. Bu projeye 1998 yılında Milli Eğitim Bakanlığı ve Yükseköğretim Kurulunun oluşturduğu çalışma grupları ile başlanmış, bu kurumların hazırladıkları öneriler tartışılarak geliştirilmiş ve yasa taslağı haline getirilerek Milli Eğitim Bakanlığı tarafından Türkiye Büyük Millet Meclisine sunulmuştur. Tasarı, 4702 Sayılı Kanun olarak 10 Temmuz 2001'de yasalaşmış ve 24458 Sayılı Resmi Gazete'de yayımlanarak yürürlüğe girmiştir (meb.gov.tr, 2013). Milli Eğitim Bakanlığı'nın hazırladığı Sınavsız Geçiş Klavuzu' nda; 2000'li yılların başlarında Türkiye' deki iş gücünün ortalama \% 77'sinin ilköğretim, \% 15'inin ortaöğretim ve \% 8'inin de yükseköğretim düzeyinde eğitim aldığından ve bu kadar düşük eğitim seviyesi ile Türk endüstrisinin gelişmiş ülkelerle rekabet etmesinin mümkün olmadığından da bahsedilmektedir. Ayrıca yapılan araştırmalara göre; 2000'li yıllarda iş dünyasının iş gücü ihtiyacının dörtte üçünün ön lisans seviyesinde eğitimle yetiştirilmesi gereğinin de üzerinde durulmaktadır (meb.gov.tr, 2013).

Yapılan bu çalışmalardan sonra elde edilen gelişmeleri gözlemleyebilmek için günümüzdeki lise mezunlarının mezun oldukları liselere göre lisans ve ön lisans programlarına yerleştirilme oranlarına bakılabilir. Bu amaçla 2011-2012 eğitim öğretim döneminde meslek liseleri ve diğer liselerden mezun olan ve lisans ve ön lisans programlarına yerleştirilen öğrencilerin sayı ve oranları Tablo 3' de verilmektedir.

Tablo 3: 2011-2012 Döneminde Meslek Liseleri/Diğer Liselerden Mezun Olan ve Lisans/Ön Lisans Programlarına Yerleştirilen Öğrenci Sayıları

\begin{tabular}{|r|c|c|c|c|c|}
\hline \multirow{2}{*}{ Mezun Olunan Lise } & Mezun Miktarı & \multicolumn{2}{|c|}{ Lisans Programına Yerleşme } & \multicolumn{2}{c|}{ Ön Lisans Programın Yerleşme } \\
\cline { 2 - 6 } & Sayı & Sayı & Oran & Sayı & Oran \\
\hline Meslek Liseleri & 533.512 & 33.493 & 6 & 143.664 & 27 \\
\hline Diğer Liseler & 1.759 .403 & 350.911 & 20 & 253.511 & 14 \\
\hline Toplam & 2.292 .915 & 384.404 & 16 & 397.175 & 17 \\
\hline
\end{tabular}

Kaynak: tuik.gov.tr, 2013.

Tablo 3'e bakarsak tüm liselerden mezun olan öğrencilerin yaklaşık \%33'ünün bir yükseköğretim programına yerleştirildiğini ve bu öğrencilerin \%16'sının lisans, \%17'sinin ön 
lisans programlarında öğrenim görmeye hak kazandıklarını görürüz. Meslek lisesi mezunlarının \%33'ü bir yükseköğretim kurumuna yerleştirilirken, diğer liselerden mezun olan öğrencilerin \% 34'ünün yükseköğretim kurumlarına yerleşmesi sağlanmıştır. Bu sonuçlar göstermektedir ki mezun olunan lise herhangi bir yükseköğretim kurumuna yerleşmeyi etkilememektedir. Farklılık mezun öğrencilerin yerleştirildikleri programlarda kendisini göstermektedir. Meslek lisesi çıkışlı öğrencilerin \%6'sı lisans, \%27'si ön lisans ve diğer lise çıkışlıların \%20'si lisans, \%14'ü ön lisans programlarına yerleştirilmiştir. Bu açıdan tek farklılığın meslek lisesi çıkışlıların ağırlıklı olarak ön lisans programlarına, diğer lise çıkışlıların ise ağırlıklı olarak lisans programlarına yerleşmiş olmasında görülmektedir. $\mathrm{Bu}$ bulgular sınavsız geçiş sisteminin arzulanan amaca ulaşılmasında bir yere kadar hizmet ettiğini göstermektedir.

Türkiye'de meslek yüksekokullarının ve meslek liselerinin yeniden yapılandırılması sürecinde çok yollar kat edilmiş olmasına rağmen, çok olumlu sonuçlar alınmadığı da gözlenmektedir. $\mathrm{Bu}$ gözlemleri bu alanda çalışma yapan araştırmacıların bulguları da kanıtlamaktadır. Sönmez (2008, s.71) son yıllarda mesleki ve teknik orta öğretimde yaşanan çöküşten ve bu çöküşün sonucunda meslek yüksekokulları ve mühendislik eğitiminde yaşanan olumsuzluklardan bahsetmektedir. Tunç (2005:80) ise sınavsız geçişin meslek liseleri öğrencilerini "nasıl olsa meslek yüksekokuluna yerleştirilecekleri” anlayışı nedeniyle üniversite sınavı için çaba göstermekten alıkoyduğu; meslek liselerinden yeterli donanımı elde etmeden gelen öğrencilerin meslek yüksekokullarında başarıyı düşürdüğü, meslek yüksekokullarından ayrılma oranlarının yüksek olduğu ve bu bağlamda meslek yüksekokulu öğrencilerinin hem kalite hem de sayısında düşüş olduğu yönündeki bulgulara dikkat çekmektedir. Kızgın'ın (2005:120) 872 meslek yüksekokulu öğrencisi üzerinde gerçekleştirdiği ve sınavsız geçiş sistemiyle meslek yüksekokullarına gelen öğrencilerin başarılarını test ettiği analiz sonuçları da, bu sistemle gelen öğrencilerin sınavla gelen öğrencilere oranla başarısız olduklarını ortaya koymaktadır. Henden'in (2006:165-166) sınavsız geçiş üzerine yapmış olduğu çalışmada benzer sonuçlar ortaya koymakta, sistemin meslek yüksekokullarındaki başarısızlığı artırdığı ve bu sistemle gelen öğrencilerin bu sistemden memnun olmadıklarını göstermektedir. Nartgün ve Yüksel'in (2009:202-203) meslek yüksekokullarında çalışan öğretim elemanları üzerinde yapmış oldukları çalışma sonuçları da, sınavsız geçiş sisteminin değiştirilmesi ve yeniden düzenlenmesi gerektiği yönünde bulgulara yer vermektedir.

\section{MESLEKİ EĞİTIM KAVRAMI}

Meslek; bireylerin hayatlarını sürdürülebilir kılmak ve aldıkları eğitim sayesinde kazandıkları bilgi ve becerileri ortaya koymak imkanı sağlayan her türlü faaliyetin toplamıdır. Karcıoğlu ve arkadaşları (2010:4) mesleğin, bir tür bireyin kendini ve yeteneklerini geliştirme yolu olduğunu belirtir. Eğitim ise bireye yeni becerilerin kazandırılma süreci olarak 
tanımlanabilir. Aynı zamanda eğitim; bilgi çağının en değerli yapı taşı olarak tüm ekonomilerin dikkatini çeken bir numaralı rekabet gücü aracıdır.

Mesleki eğitim ise; içerisinde eğitimdeki yeni oluşumları barındıran geniş bir kavramdır. Çelenk ve Çamtosun (2009:160) bu kavramı, bireye iş hayatında geçerliliği olan bir meslek için gerekli bilgi, beceri ve iş alışkanlıkları kazandırma ve ferdin yeteneklerini, işi bir araç olarak kullanarak çeşitli yönleriyle geliştirme süreci olarak ifade eder.

Yeni ekonomik düzen ekonomik faaliyet alanlarını çeşitlendirerek yeni iş kollarının ortaya çıkmasını tetiklemiş, bu yeni iş kolları da kendisine uygun elemanların istihdam edilmesini zorunlu hale getirmiştir. Personelin yeni üretim sahalarıyla uyumlu hale getirilmesi ise mesleki eğitim sürecinin etkinliğine bağlı olarak hızlı ya da yavaş bir şekilde gerçekleşir. Etkin bir eğitim süreci, eğitimden sorumlu olan birimlerin iş piyasalarıyla iş birliği içerisinde bulunarak, gelişmiş ülkelerin eğitim süreçlerini yakından takip ederek, elde edinilen bilgileri ülke ekonomisinin tüm gerçeklerini göz önüne alarak işlerlik kazanacaktır. Ayrıca planlama yapılırken eğitimin sadece tek kademesi için değil, tüm kademeleri için yapılması, elde edilecek sonuçların başarı şansını artıracaktır.

Temel (1996:6) mesleki eğitimin ülke ekonomileri için neden önemli ve zorunlu olduğunu birkaç başlık altında toplamıştır: (1) İşgücü piyasasının ihtiyaçlarını karşılamak, (2) üretimde verimlilik ve kalite artışı yaratmak, (3) işsizliği azaltmak, (4) ucuz ama kaliteli mal ve hizmet üretmek, (5) kaynakları etkin bir şekilde kullanmak, (6) çağdaş üretim teknolojilerini takip ederek, mal ve hizmet üretimine yansıtmak, (7) ekonomik kalkınmayı desteklemek.

Gelişmekte olan ekonomilerin pek çok kronik sorunu bulunmaktadır ve bu sorunların başında da işsizlik gelir. Gelişmekte olan ülkeler bir yandan eğitim sistemlerini güncellemeye ve yeni teknolojik gereklere uydurmaya çalışırken, diğer yandan artan nüfusa iş imkanları yaratmakla mücadele etmek zorunda kalmaktadırlar. Kazu ve Demirli (2002) bu noktada eğitim kurumlarına büyük görev düştügünü, eğitim kurumlarının işsizlik problemine gerekli hassasiyeti göstererek niteliksiz ve üretime katkıda bulunmayan nüfus oluşumuna engel olabileceğini özellikle vurgulamaktadır. Meslekî ve teknik eğitim kurumlarının günün şartlarına uyarlanması sayesinde nitelikli insan gücü yetiştirilmesinin önü açılarak istihdam sorununa ve sektörler arasındaki dengenin sağlanmasına önemli katkı sağlanabilecektir.

\section{MUHASEBECİIIK MESLEĞİ VE MESLEK YÜKSEKOKULLARINDA MUHASEBE EĞİTIMI}

Türkiye'de muhasebecilik mesleğinin tüm ayrıntıları 3568 sayılı "Serbest Muhasebecilik, Serbest Muhasebeci Mali Müşavirlik ve Yeminli Mali Müşavirlik” kanunu ile düzenlenmiş olup, 26.07.2008 tarihinde yürürlüğe giren 5786 sayılı kanun 3568 sayılı kanunda bazı değişiklikler yapılmıştır. Bu düzenleme ile ticaret meslek lisesi ve muhasebe ön lisans programlarından mezun olanların gerekli kanuni şartları da sağlamak kaydıyla serbest muhasebeci unvanıyla çalışabilirlikleri ellerinden alınmıştır. Serbest Muhasebeci ve Serbest 
Muhasebeci Mali Müşavir unvanı tek bir isim altında toplanarak Serbest Muhasebeci Mali Müşavir olarak yenilenmiştir. Bu ünvana sahip olabilmek için eğitim koşulu olarak da hukuk, iktisat, maliye, işletme, muhasebe, bankacılık, kamu yönetimi ve siyasal bilimler dallarında eğitim veren fakülte ve yüksekokullardan en az lisans düzeyinde mezun olma şart1 getirilmiştir (3568 sayılı kanunda 26.07.2008 tarihinde gerçekleştirilen düzenleme).

Muhasebe eğitimi kavramı ise yıllar önce taşıdığı anlamdan hiçbir şey kaybetmemiş, sadece geçmişteki açıklamalarına yeni ekonomik düzenin getirdiği bazı değerleri ilave ederek geliştirmek zorunda kalmıştır. Aysan (1979: 254) yıllar önce yapmış olduğu muhasebe eğitimi tanımında, bu eğitimin işletme için faydalı olan her türlü bilginin saptanıp, derlenip, ölçülüp, işlenip, denetlenip, rapor edilmesi ve bu raporların gerektiğinde nasıl okunması gerektiğinin öğrencilere öğretilmesi ve öğrencilerin öğrendikleri bilgileri uygulamalarının sağlanması süreci olduğunu belirtir. Özbirecikli ve Pastacıgil (2009:82) ise muhasebe eğitimin 21.yy’da değişen içeriğinde muhasebecilerin sürekli değişime ayak uydurabilmesinin, önemli ölçüde mesleki bilgi, beceri, etik ve niteliklere bağlı olduğuna, muhasebeci olmak isteyenlerin yenilikleri öğrenme ve uygulama konusunda istekli olması ve meslek mensuplarının yaşam boyu öğrenme sürecine dahil olması gerektiğine değinmektedir. Bu noktada öğrencilerin aldığ 1 muhasebe eğitimi temel belirleyici konumundadır (Karcıoğlu vd., 2010:4). Daştan da (2009:144) benzer bir şekilde muhasebe eğitiminde kaliteli bilgi üretecek bireyleri yetiştirme sorumluluğunun gün geçtikçe arttığına vurgu yapar.

Türkiye'de muhasebe eğitimi Ticaret Meslek Liselerinde, Meslek Yüksekokullarının Muhasebe Programlarında ve İktisadi ve İdari Bilimler Fakültelerinin hemen hemen tüm programlarında en yoğun haliyle verilmektedir. 4702 sayılı kanun ile 2002-2003 eğitim öğretim döneminden itibaren Ticaret Meslek Lisesi çıkışlı öğrencilere alanlarıyla ilgili meslek yüksekokullarına sınavsız geçiş hakkının verilmesiyle Ticaret Meslek Liseleri ve Meslek Yüksekokullarının birbirlerine bir tür bağlantısı gerçekleştirilmiştir. Bu ilişki sonuç itibariyle ticaret meslek liseleri ve ilgili meslek yüksekokulunun verdiği muhasebe eğitimini daha da yoğunlaştırmıştır ${ }^{1}$.

Sınavsız geçiş sisteminin beklenen sonucu vermesi, bir bakıma meslek lisesi öğrencilerinin bu uygulamaya bakış açısına da bağlı olacaktır. Genelde meslek lisesi öğrencilerinin bu liseleri tercih etmelerinde aile faktörünün ağırlığı olduğu düşünülür. Bu seçimde ailenin geliri ve eğitim düzeyi oldukça önemli faktörlerdir (Demir ve Subaşı, 2008 ve Mauldin, Crain ve Maunce, 2000). Demir ve Subaşı (2008:97) yapmış oldukları çalışma sonucunda ticaret meslek lisesi öğrencilerinin yüksek öğrenime devam etmek için öncelikle üniversite sınavına girmek istedikleri, kazanamadıkları taktirde sınavsız geçiş hakkını kullanmayı tercih edecekleri yönünde bulgulara ulaşmışlardır. Meslek yüksekokulunda okumak aslında bir tercih olarak değil, bir zorunluluk olarak kendini göstermektedir.

\footnotetext{
${ }^{1}$ Ayrıntılı bilgi için bknz. meb.gov.tr sınavsız geçiş.
} 
Gücenme Gençoğlu ve İşseveroğlu'nun (2010:38) meslek yüksekokullarındaki eğitimin muhasebe mesleğine katkısı üzerine yaptıkları çalışmanın sonuçları; meslek yüksekokulu sayılarının hızla artmasına rağmen, bu okul mezunlarının başarısının hızla azaldığını ortaya koymaktadır. Gücenme Gençoğlu ve İşseveroğlu ( 2010:38) bu sonucun gerekçesi olarak sınavsız geçiş sistemini, öğrencilerin motivasyon eksikliklerini, eğitmenlerin mesleki bilgilerini geliştirme yönündeki isteksizliklerini göstermektedir.

Çelenk ve Çamtosun $(2009: 168,172)$ ticaret meslek lisesi çıkışlı bir grup meslek yüksekokulu öğrencisi üzerinde gerçekleştirdiği çalışmada; ticaret meslek lisesinde alınan muhasebe bilgisinin, ön lisans bölümlerindeki muhasebe derslerine yeterli altyap1 oluşturduğunu düşünen öğrencilerin ağırlıklı olduğu (\%72), bunun yanı sıra ticaret meslek liselerinde alınan muhasebe derslerinin yükseköğretimdeki muhasebe derslerinin kalitesini artırdığı $(\% 69,1)$ yönünde bulgulara rastlamıştır. Elde edilen bu sonuçlar birbiriyle paralellik arz etmekte olup, ticaret meslek liselerinin meslek yüksekokulları için olumlu bir durum yarattığının göstergesi olarak değerlendirilebilir.

Kavi (2007:31); meslek yüksekokulları yöneticilerinin meslek lisesi mezunlarının sınavsız olarak meslek yüksekokullarına yerleştirilmelerini yanlış bulduklarını, ayrıca düz liseden gelen öğrenciler ile bu öğrenciler arasında ciddi miktarda nitelik farkları bulunması nedeniyle, meslek yüksekokullarından istenilen eğitim performansının sağlanamadığından şikayetçi olduklarını belirtmektedir.

Gerçekten de meslek yüksekokulları çalışanları meslek liselerinden mezun olan öğrencilere sınavsız geçiş imkanının sağlanmasıyla meslek yüksekokullarında öğrenci ve öğretim kalitesinin düştüğünden şikayet etmektedir. İşte bu bağlamda bu çalışma ile meslek yüksekokullarına düz lise (sınavlı) ya da meslek liselerinden (sınavsız) gelen öğrencilerin gerçekten de meslek yüksekokullarının başarısını etkileyip etkilemediği araştırılmaktır. Ayrıca bu değerlendirme yapılırken, meslek yüksekokuluna yerleştirilen öğrencilerin; birinci ya da ikinci öğretimde okuyor olmalarının ders başarısı üzerindeki etkisi de incelenmektedir.

\section{5. ÇALIŞMANIN KAPSAM, YÖNTEM VE BULGULARI}

\section{1 Çalışmanın Kapsamı}

Çalışmanın hedef kitlesi Süleyman Demirel Üniversitesi Eğirdir Meslek Yüksekokulu Muhasebe ve Vergi Uygulamaları Birinci ve İkinci Öğretim Programlarına 2012-2013 eğitim ve öğretim döneminde kayıt yaptıran ve derslere devam eden 55 öğrencidir. Çalışmada Genel Muhasebe ve Ekonomi derslerindeki öğrenci başarı ortalamaları öğrencilerin demografik özelliklerine göre değerlendirilecek ve farklılıklar irdelenmeye çalışılacaktır. Muhasebe dersinin seçilme nedeni Muhasebe ve Vergi Uygulamaları bölümünün temel dersi olması, aynı zamanda meslek liseliler için bilinen ve düz lise mezunları için farklı bir ders olmasıdır. Ekonomi dersinin seçilme nedeni ise; bu dersin sözel ağırlıklı, güncel içerikli ama yine düz lise öğrencileri için ilk kez alacakları farklı özellikli bir ders olmasıdır. Çalışmada hedef kitle 
olarak belirlenen 55 öğrenciye ait demografik özelikler ve çalışma kapsamında değerlendirilecek bazı özellikler tablo 4'de verilmektedir.

Tablo 4: Hedef Kitlenin Demografik Özellikleri

\begin{tabular}{|l|c|c|c|}
\hline \multicolumn{2}{|c|}{ DEMOGRAFIK ÖZELLIKLER } & Sayı & $\%$ \\
\hline Cinsiyet & Kız & 35 & 64 \\
\cline { 2 - 4 } & Erkek & 20 & 46 \\
\hline \multirow{2}{*}{ Öğretim Türü } & Birinci Öğretim & 37 & 67 \\
\cline { 2 - 4 } & İkinci Öğretim & 18 & 33 \\
\hline Mezun Olunan Lise & Düz Lise & 38 & 69 \\
\cline { 2 - 4 } & Meslek Lisesi & 17 & 31 \\
\hline
\end{tabular}

Hedef kitle olarak belirlenen 55 öğrencinin 35 tanesi kız, 20 tanesi erkektir. $\mathrm{Bu}$ öğrencilerden 37 tanesi Birinci Öğretim, 18 tanesi İkinci Öğretimde eğitim görmektedir. Yine bu öğrencilerin 38 tanesi düz lise, 17 tanesi meslek lisesi çıkışlıdır.

Öğrencilerin seçilen iki ders açısından sınıf geçme ve sınıfta kalma durumları Tablo 5'de verilmektedir.

Tablo 5: Öğrencilerin Başarı Durumlarının Sayı ve \% olarak Görünümü

\begin{tabular}{|c|c|c|c|c|c|c|c|}
\hline \multirow{3}{*}{ Dersler } & \multirow{3}{*}{ Mezun Olunan Lise } & & & \multicolumn{4}{|c|}{ Başarı Durumları } \\
\hline & & & & \multicolumn{2}{|c|}{ Geçen Öğrenci } & \multicolumn{2}{|c|}{ Kalan Öğrenci } \\
\hline & & Sayı & $\%$ & Sayı & $\%$ & Sayı & $\%$ \\
\hline \multirow{3}{*}{ Genel Muhasebe } & Meslek Lisesi & 17 & 31 & 9 & 53 & 8 & 47 \\
\hline & Düz Lise & 38 & 69 & 25 & 66 & 13 & 34 \\
\hline & TOPLAM & 55 & 100 & 34 & 62 & 21 & 38 \\
\hline \multirow{3}{*}{ Ekonomi } & Meslek Lisesi & 17 & 31 & 12 & 71 & 5 & 29 \\
\hline & Düz Lise & 38 & 69 & 32 & 84 & 6 & 16 \\
\hline & TOPLAM & 55 & 100 & 44 & 80 & 11 & 20 \\
\hline
\end{tabular}

Hedef kitlenin \%31'i meslek lisesi, \%69'u düz lise mezunudur. Toplamda muhasebe dersindeki başarı \%62 ve ekonomi dersindeki başarı \%80 olarak bulunmuştur. Ayrıca her iki derste de düz lise çıkışlıların meslek liselerine oranla daha başarılı oldukları görülmüştür. $\mathrm{Bu}$ oranlar muhasebe dersinde \%66'ya karş1lık \%53, ekonomi dersinde \%84'e karşılık \%71 şeklinde ortaya çıkmıştır.

\section{2. Çalışmanın Yöntemi}

Çalışmada öğrencilerin aldıkları notlar dikkate alınarak faktöriyel düzende tekrarlanan ölçümlü varyans analizi tekniği (SPSS istatistik programında) uygulanmıştır. Yine bu çalışmada cinsiyet faktörünün kı//erkek olmak üzere 2 seviyesi, öğretim türü faktörünün birinci öğretim/ikinci öğretim olmak üzere iki seviyesi, mezun olunan lise faktörünün düz lise/meslek lisesi olmak üzere iki seviyesi ve başarısı ölçülen dersler faktörünün muhasebe/ekonomi olmak üzere iki seviyesi mevcuttur. Tekrarlanan ölçümler ders faktörünün seviyelerinde gerçekleştirilmiştir. 


\section{3. Çalışmanın Bulguları}

Katılımcı öğrencilerin cinsiyetlerinin kız ya da erkek olmasının incelenen derslerdeki (muhasebe ve ekonomi) başarı üzerinde bir farklılık yaratıp yaratmadığı test edilmiştir. Bu amaçla aşağıdaki hipotez kurulmuştur.

H1: Öğrencilerin cinsiyet ve ders başarılarının not ortalamaları arasında istatistik olarak fark vardır.

Tablo 6: Cinsiyet ve Ders Başarıları

\begin{tabular}{|c|c|c|c|c|}
\hline & & & \multicolumn{2}{|c|}{ 95\% Güven Aralı̆̆ } \\
\cline { 4 - 5 } Cinsiyet & Ortalama & Standart Sapma & Alt Sinır & Üst Sınır \\
\hline Erkek & 40,431 & 3,859 & 32,668 & 48,193 \\
\hline KıZ & 43,021 & 3,188 & 36,608 & 49,434 \\
\hline
\end{tabular}

Öğrencilerin cinsiyetlerinin kız ya da erkek olması ve ders başarılarının not ortalamaları arasındaki farklar istatistik olarak önemli değildir. Bu durumda kurulmuş olan hipotez reddedilir. Cinsiyet için ders başarıları ile ilgili ortalamalar birbirine yakındır $(40,431$ 43,021). Ayrıca güven aralıkları birbiri ile kesişmektedir. (Erkeklerin ders başarılarının güven aralığı 32,668' den 48,193'e kadardır. Kızların ders başarılarının güven aralığı ise 36,608'den başlamaktadır ve 49,434'e kadardır.) Diyebiliriz ki cinsiyet faktörü tek başına ders başarısı değişkeni üzerinde anlamlı bir etkiye sahip değildir.

Muhasebe programı I. sınıf öğrencilerin birinci ya da ikinci öğretimde okuyor olmasının incelenen derslerdeki (muhasebe ve ekonomi) başarı üzerinde bir farklılık yaratıp yaratmadığı test edilmiştir. Bu amaçla aşağıdaki hipotez kurulmuştur.

H1: Öğrencilerin öğretim türlerinin ve ders başarılarının not ortalamaları arasında istatistik olarak fark vardır.

Tablo 7: Öğretim Türü ve Ders Başarıları

\begin{tabular}{|c|c|c|c|c|}
\hline & & Standart & \multicolumn{2}{|c|}{ 95\% Güven Aralı̆̆ı } \\
\cline { 4 - 5 } Ö̈̆retim türü & Ortalama & Sapma & Alt Sınır & Üst Sınır \\
\hline Birinci Öğretim & 48,396 & 3,008 & 42,346 & 54,446 \\
\hline İkinci Öğretim & 35,056 & 4,001 & 27,007 & 43,104 \\
\hline
\end{tabular}

Öğrencilerin birinci ya da ikinci öğretimde okuyor olması ve ders başarılarının not ortalamaları arasındaki farklar istatistik olarak önemlidir. Bu durumda kurulan hipotez kabul edilir. Öğretim türü için ders başarıları ile ilgili ortalamalar birbirinden oldukça uzaktır (48,396-35,056). Diyebiliriz ki öğretim türü faktörü tek başına ders başarısı değişkeni üzerinde anlamlı bir etkiye sahiptir.

Katılımcı öğrencilerin mezun oldukları liselerin düz lise ya da meslek lisesi olmasının incelenen derslerdeki (muhasebe ve ekonomi) başarı üzerinde bir farklılık yaratıp yaratmadığı test edilmiştir. $\mathrm{Bu}$ amaçla aşağıdaki hipotez kurulmuştur. 
H1: Öğrencilerin mezun oldukları liselerin ve ders başarılarının not ortalamaları arasında istatistik olarak fark vardır.

Tablo 8: Mezun Olunan Okul ve Ders Başarıları

\begin{tabular}{|l|c|c|c|c|}
\hline Mezuniyet & & Standart & \multicolumn{2}{|c|}{ 95\% Güven Aralı̆̆ } \\
\cline { 4 - 5 } & Ortalama & Sapma & Alt Sinır & Üst Sınır \\
\hline Düz Lise & 41,639 & 2,976 & 35,651 & 47,627 \\
\hline Meslek Lisesi & 41,812 & 4,024 & 33,717 & 49,908 \\
\hline
\end{tabular}

Öğrencilerin düz lise ya da meslek lisesi mezunu olması ve ders başarılarının not ortalamaları arasındaki farklar istatistik olarak önemli değildir. Bu durumda kurulan hipotez reddedilir. Mezun olunan lise türü için ders başarıları ile ilgili ortalamalar birbirine yakındır (41,639-41,812). Ayrıca güven aralıkları birbiri ile kesişmektedir. (Düz lise mezunlarının ders başarılarının güven aralığı 35,651'den 47,627'ye kadardır. Meslek lisesi mezunlarının ders başarılarının güven aralığı ise 33,717'den başlamaktadır ve 49,908'e kadardır.) Diyebiliriz ki mezun olunan lise faktörü tek başına ders başarısı değişkeni üzerinde anlamlı bir etkiye sahip değildir.

Katılımcı öğrencilerin aldıkları derslerin sözel (ekonomi) yanda sayısal (muhasebe) içerikli olmasının; ya da bir başka açıdan ilk defa alınıyor ya da daha önce hiç alınmamış olmasının incelenen derslerdeki (muhasebe ve ekonomi) başarı üzerinde bir farklılık yaratıp yaratmadığı test edilmiştir. Bu amaçla aşağıdaki hipotez kurulmuştur.

H1: Öğrencilerin aldıkları derslerin türünün ve ders başarılarının not ortalamaları arasında istatistik olarak fark vardır.

Tablo 9: Dersler ve Ders Başarıları

\begin{tabular}{|l|r|r|r|r|}
\hline & & & \multicolumn{2}{|c|}{ 95\% Güven Aralı̆̆ } \\
\cline { 4 - 5 } Ders & Ortalama & Standart Sapma & Alt Sınır & \multicolumn{1}{c|}{ Üst Sınır } \\
\hline Muhasebe & 36,960 & 3,576 & 29,766 & 44,154 \\
\hline Ekonomi & 46,491 & 1,892 & 42,685 & 50,298 \\
\hline
\end{tabular}

Öğrencilerin muhasebe ya da ekonomi dersi alıyor olmasının ve ders başarılarının not ortalamaları arasındaki farklar istatistik olarak önemlidir. Bu durumda kurulan hipotez kabul edilir. Dersin türü (ekonomi ya da muhasebe) için ders başarıları ile ilgili ortalamalar birbirinden oldukça uzaktır $(36,960-46,491)$. Diyebiliriz ki dersin türü faktörü tek başına ders başarısı değişkeni üzerinde anlamlı bir etkiye sahiptir. 
Tablo 10: Cinsiyet * Öğretim türü * Mezuniyet * Ders

\begin{tabular}{|c|c|c|c|c|c|c|c|}
\hline \multirow[t]{2}{*}{ Cinsiyet } & \multirow[t]{2}{*}{ Öğretim Türü } & \multirow[t]{2}{*}{ Mezuniyet } & \multirow[t]{2}{*}{ Ders } & \multirow[b]{2}{*}{ Ortalama } & \multirow{2}{*}{$\begin{array}{c}\text { Standart } \\
\text { Sapma }\end{array}$} & \multicolumn{2}{|c|}{ 95\% Güven Aralığı } \\
\hline & & & & & & Alt Sinir & Üst Sınır \\
\hline \multirow[t]{8}{*}{ Erkek } & \multirow[t]{4}{*}{ Birinci Öğretim } & \multirow[t]{2}{*}{ Düz Lise } & Muhasebe & 37,833 & 8,542 & 20,650 & 55,017 \\
\hline & & & Ekonomi & 46,833 & 4,519 & 37,741 & 55,925 \\
\hline & & \multirow[t]{2}{*}{ Meslek Lisesi } & Muhasebe & 37,000 & 12,080 & 12,699 & 61,301 \\
\hline & & & Ekonomi & 50,000 & 6,391 & 37,142 & 62,858 \\
\hline & \multirow[t]{4}{*}{ İkinci Öğretim } & \multirow[t]{2}{*}{ Düz Lise } & Muhasebe & 32,556 & 6,974 & 18,525 & 46,586 \\
\hline & & & Ekonomi & 46,222 & 3,690 & 38,799 & 53,646 \\
\hline & & \multirow[t]{2}{*}{ Meslek Lisesi } & Muhasebe & 31,000 & 14,794 & 1,237 & 60,763 \\
\hline & & & Ekonomi & 42,000 & 7,828 & 26,252 & 57,748 \\
\hline \multirow[t]{8}{*}{ Kız } & \multirow[t]{4}{*}{ Birinci Öğretim } & \multirow[t]{2}{*}{ Düz Lise } & Muhasebe & 50,000 & 4,678 & 40,588 & 59,412 \\
\hline & & & Ekonomi & 53,000 & 2,475 & 48,020 & 57,980 \\
\hline & & \multirow[t]{2}{*}{ Meslek Lisesi } & Muhasebe & 60,375 & 7,397 & 45,494 & 75,256 \\
\hline & & & Ekonomi & 52,125 & 3,914 & 44,251 & 59,999 \\
\hline & \multirow[t]{4}{*}{ İkinci Öğretim } & \multirow[t]{2}{*}{ Düz Lise } & Muhasebe & 27,667 & 12,080 & 3,366 & 51,968 \\
\hline & & & Ekonomi & 39,000 & 6,391 & 26,142 & 51,858 \\
\hline & & \multirow[t]{2}{*}{ Meslek Lisesi } & Muhasebe & 19,250 & 10,461 & $-1,795$ & 40,295 \\
\hline & & & Ekonomi & 42,750 & 5,535 & 31,615 & 53,885 \\
\hline
\end{tabular}

Yapılan varyans analizi sonucunda ders*cinsiyet*öğrenim türü*mezuniyet dörtlü interaksiyonu ve tüm 3'lü ve 2'li interaksiyonlar istatistik olarak önemli değildir. Fakat derslerin not ortalamaları arasındaki farklar istatistik olarak önemlidir $(p<0,01)$. Ayrıca birinci öğretim ve ikinci öğretim not ortalamaları arasındaki farklar da önemlidir $(\mathrm{p}<0,05)$. Fakat cinsiyet ve mezun olunan okul ile not ortalamaları arasındaki farklar istatistik olarak önemli değildir.

\section{SONUÇ}

Çalışma düz liselerden sınavla, meslek liselerinden sınavsız olarak meslek yüksekokullarına geçiş yapan öğrenciler arasında bazı demografik özelliklere göre ders başarıları açısından bir farklılık olup olmadığını test etmek için gerçekleştirilmiştir. Yapılan istatistik analizden elde edilen sonuçları 3 başlık altında toplamak mümkündür. Bunlar:

1. Dersler arasında zorluk derecelerinde farklılıklar bulunmaktadır. Ayrica ders başarısı üzerinde esas farklılı yaratan faktör; alınan dersin türü ve öğrencilerin yerleştirildiği öğretim türüdür. Muhasebe dersinde başarı oranı yaklaşık \%37, ekonomi dersinde ise \%46 olarak bulunmuştur. Dersin türü tek başına ders başarısı üzerinde anlamlı bir etkiye sahiptir. Kanaatimizce meslek derslerinin bu dersi ilk kez alan düz lise mezunları için zorlayıcı olması normal olarak değerlendirilebilir. Ama meslek lisesinde bu dersi görmüş olan öğrencilerin de bu tür bir derste zorlanması, mesleki eğitimin lise aşamasında yeniden gözden geçirilmesini zorunlu kılmaktadır.

2. Birinci ögrretim ve ikinci ögrretim programlarına yerleştirilen öğrencilerin not ortalamaları arasında farklılıklar bulunmaktadır. I. öğretimde okuyan öğrencilerin not ortalamaları \%48, II. öğretimde okuyan öğrencilerin not ortalamaları \%35'dir. Birinci 
öğretime kayıt yaptıran öğrenciler ikinci öğretime kayıt yaptıranlardan her iki derste de daha başarılıdır. Sınavsız geçiş ile meslek lisesi mezunlarının bilgi ve becerilerinin artırılması amacından ödün verilmeden, isteyen düz lise mezunu öğrencilere de kısa yoldan meslek edinme şansı sağlandığı söylenebilir. Fakat yine de her iki grup öğrenci için derslerde mevcut olan genel başarısızlık durumunun, liselerde (düz/meslek) verilen eğitimin yeniden değerlendirilerek gözden geçirilmesini gerektirdiğini belirtmek gerekir.

3. Cinsiyet ve mezun olunan okulun öğrencilerin ders başarıları üzerinde farklılık

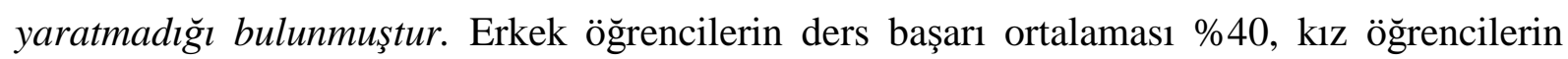
ders başarı ortalaması \%43' dür. Düz lise mezunlarının ve meslek lisesi mezunlarının ders başarı ortalamaları yaklaşık olarak aynıdır (yaklaşık \%42). Meslek yüksekokullarında öğrenim gören öğrencilerin düz liseden ya da meslek liselerinden bu okullara gelmiş olması (sınavlı/sınavsız) ve bu öğrencilerin kız ya da erkek olması ders başarıları arasında farklılık yaratmamaktadır.

Çalışmamızın sonucunda elde edilen bulgular öğrenci kalitesinin düştüğü yönündedir. Ama bu kalite kaybının ne öğrencilerin sınavla düz liselerden ne de sınavsız meslek lisesinden gelmesinden; ne kız ne de erkek olmasından kaynaklanmadığı ortadadır. Esas problem öğrencilere verilen derslerin özelliğinden ve öğrencilerin yerleştirildikleri öğretim türünden kaynaklanmaktadır. Bu durumu biraz daha açacak olursak; meslek dersleri öğrencilere zor gelmektedir. Mesleki dersi ilk kez gören de, daha önce görmüş olan da bu derste zorlanmaktadır. Ayrıca birinci öğretime devam eden öğrencilerin ikinci öğretime devam edenlere oranla daha başarılı oldukları tespit edilmiştir. Birinci öğretime gelen öğrenciler sınavlı ya da sınavsız olarak bu öğretim türüne yerleştirilmiş olmalarına rağmen, ikinci öğretime yerleştirilenlerden daha iyi bir başarı gösterdikleri için (lise mezuniyet notları ve üniversite sınav notları açısından) bu öğretimde bulunmaktadırlar. Bu durum iki öğretim türü arasında başarı açısından farklılıklar ortaya çıkmasına sebep olmaktadır.

Son bir söz olarak diyebiliriz ki; uğraşılması ve üzerinde düşünülüp çözüm üretilmesi gereken konu, sınavsız geçiş ya da sınavsız geçişin ortaya çıkardığı düşünülen meslek yüksekokulu eğitim kalitesindeki azalışlar değil, hem düz lise hem de meslek liselerindeki eğitim kalitesindeki azalışlar olmalıdır. Kanaatimize göre; Türkiye'deki kalkınma politikaları içerisinde eğitim politikası öncelikli olarak ele alınmalı, ülkenin eğitim atmosferini etkileyecek her alt başlık çok iyi incelendikten sonra yeni bir politika uygulaması başlatılmalıdır. Her ülkenin gerçeklerinin farklı olduğu ve bu farklılıklara göre yenilik sistemlerinin düzenlenmesi gerektiği asla unutulmamalıdır.

\section{KAYNAKLAR}

Aysan, Mustafa A. (1979), “Türkiye'de Muhasebe Eğitimi Nasıl Yapılmalıdır?”, Türkiye I. Muhasebe Eğitimi Sempozyumu, (20-21 Nisan 1979, Antalya), Ss. 250-284.

Çelenk, Hakan ve Çamtosun, İsa (2009), “Ticaret Meslek Liselerinde Verilen Muhasebe Eğitiminin Kalitesi ve Bu Eğitimin Meslek Yüksekokullarındaki Muhasebe Eğitimine 
Etkilerine Yönelik Bir Uygulama” Marmara Üniversitesi Sosyal Bilimler Enstitüsü Dergisi, Cilt 8, Sayı 32, Temmuz 2009, ss. 159-173.

Daştan, Abdülkerim (2009), "Karadeniz Teknik Üniversitesi IÏBF Ölçeğinde Akademik Görünüm Ve Muhasebe Eğitiminin Değerlendirilmesine Yönelik Bir Araştırma", Muhasebe Finansman Dergisi, Say1 42, ss. 144-156.

Demir, Berna ve Subaşı, Şerife (2008), "Muhasebe Programlarına Sınavsız Geçiş Hakkı Olan Öğrencilerin Profili Ve Muhasebe Mesleğine Bakışları", Muhasebe Finansman Dergisi, Sayı 37, ss.88-97.

Gücenme Gençoğlu, Ümit ve İşseveroğlu, Gülsün (2010), "Türkiye'de Meslek Yüksekokullarındaki Eğitimin Muhasebe Mesleğine Katkısı Üzerine Bir Araştırma", Muhasebe Finansman Dergisi, Temmuz 2010, Sayı 47, ss.28-40.

Henden, Rıfkı (2006), “Üçüncï Yılda Sınavsız Geçiş Uygulamaları: Alaplı Meslek Yüksekokulu Örneği”, ZKÜ Sosyal Bilimler Dergisi. Cilt 2, Say1 4, ss.157-168.

Karcıoğlu, Reşat; Bilgili, Bilsen ve Yazarkan, Hakan (2010), "Muhasebe Yüksek Öğrenimi Gören Öğrencilerin Kişilik Özellikleri ve Mesleğe Yönelik Düşünceleri Üzerine Bir Alan Araştırması", Muhasebe ve Denetime Bakış, ss. 1-21.

Kavi, Hüsamettin (2007). "İş Dünyasının Mesleki Eğitimden Beklentileri ve İş Dünyası Açısından Mesleki Eğitimin Önemi”, Uluslararası Mesleki ve Teknik Eğitim Konferansı, 15-16 Ocak 2007, TC Yükseköğretim Kurulu, Ankara.

Kazu, Yaşar ve Demirli, Cihad (2002), "Mesleki ve Teknik Orta Öğretim Kurumlarındaki Gelişmeler”, Milli Eğitim Dergisi, Sayı 155-156, Yaz-Güz 2002.

Kızgın, Yıldıray (2005), "Sınavsız Geçiş (METEB) Sistemi İle Gelen Öğrencilerin Başarılarının İstatistiki Analizi: Muğla Üniversitesi Muğla Meslek Yüksekokulu Örneği”, "İş, Güç" Endüstri İlişkileri ve İnsan Kaynakları Dergisi, Cilt 7, Sayı 2, Haziran 2005, ss. 119-129.

Kuşat, Nurdan ve Dolmacı, Nilgün (2011), "Ön Lisans Programlarına Ek Yerleştirme İle Yerleştirilen Öğrencilerin Sorunlarına Bir Bakış: SDÜ Isparta Meslek Yüksekokulu Örneği”, 2. Uluslararası 6. Ulusal Meslek Yüksekokulları Sempozyumu, UMYOS 2011, Kuşadası.

Kuzgun, Ylldı "Meslek Seçiminde Bilinmesi Gerekenler", http://mesbil.meb.gov.tr/mesleki_rehberlik/ogrenciler/meslek_seciminde_bilinmesi_gerek enler.pdf (02.01.2013).

Mauldin Shawn, Crain, John L. \& Maunce, Patricia H. (2000). "The Accounting Principles Instructer's Influence On Students' Decision To Major İn Accounting”, Journal of Education for Business, Cilt 75, Sayı 3, ss. 142-148.

Nartgün, Şenay ve Yüksel, Engin (2009), "Meslek Yüksekokullarına Sınavsız Geçişte İzlenen Kriterlerin Değerlendirilmesi”, Abant İzzet Baysal Üniversitesi Dergisi, Cilt 9, Sayı 2, Y11 9, Aralık. 
Özbirecikli, Mehmet ve Pastacıgil, Arın (2009), “Türkiye'de Muhasebeci Eğitiminin Gelişim Süreci: IFAC Standartları İle Mukayeseli Bir İnceleme”, Muhasebe Finansman Dergisi, Say1 41, ss.82-96.

Sönmez, Murat (2008), “Türkiye’de Mesleki Ve Teknik Örgün Öğretimin Sorunları Ve Yeniden Yapılandırılma Zorunluluğu”, Eğitim ve Bilim, Cilt 33, Sayı 147, ss. 71-84.

Temel, M. (1996) “Orta Kademede Meslekî Ve Teknik Eğitim İle Meslek Yüksekokulları Arasında Uyum Sorunları”, 21. Yüzyıla Doğru Meslek Yüksekokullarının Yeniden Yapılanması Sempozyumu, 22-23 Mayıs 1996 Çankırı, Ankara Üniversitesi Basımevi.

Tunç, Abdülkadir (2005), "Yüksekokullarına Sınavsız Geçişin Değerlendirilmesi” ZKÜ Sosyal Bilimler Dergisi, Cilt 1, Sayı 2, ss. 75-81.

3568 sayl1 kanun maddesi, www.tesmer.org.tr/Index.php?option=com_content\&view, (02.02.2013)

4702 sayılı kanun maddesi, http://mevzuat.meb.gov.tr/html/3.html, (02.02.2013).

www.meb.gov.tr.duyurular/duyurular/sinavsizgecis/sinavsizgecisklavuzu, (02.02.2013).

www.osym.gov.tr/belge/1-13575/2011-2012-ogreti-yili-yuksekogretim-istatistikleri,(01.02.2013). www.tuik.gov.tr/VeriBilgi, (01.01.2013).

www.yok.gov.tr/content/view/435, (01.01.2013).

www.yok.gov.tr/content/view/527, (01.01.2013).

YÖK (Yükseköğretim Kurulu) (2007) "Uluslararası Mesleki Ve Teknik Eğitim Konferans1Yükseköğretimde Uygulama Ağırlıklı Yeni Açılımlar”, 15-16 Ocak 2007, Ankara, Meteksan AŞ. 
